\title{
ANALISIS PENETAPAN HAKIM DALAM PEMBERIAN IZIN PERKAWINAN BEDA AGAMA DI PENGADILAN NEGERI MAKASSAR
}

\author{
Analysis of Judging Determination in Granting of Different Marriage \\ Licenses in Makassar Court
}

\author{
Cornelis H.W ${ }^{1}$, A. Muhammad Arfah P. ${ }^{2}$, Yulia A.Hasan ${ }^{2}$ \\ ${ }^{1}$ Mahasiswa Program Studi Ilmu Hukum Program Pascasarjana Universitas Bosowa \\ ${ }^{2}$ Prodi Ilmu Hukum Universitas Bosowa \\ Email: hendrawn_bjw@yahoo.com
}

Diterima: 08 Agustus 2019/Disetujui: 09 Desember 2019

\begin{abstract}
ABSTRAK
Penelitian ini bertujuan untuk mengidentifikasi pemberian izin perkawinan beda agama. Penelitian menggunakan metode kualitatif, yang bersumber dari data informan kunci, dokumen-dokumen dan wawancara serta bahan-bahan dari pustaka yang berlaku dan berkaitan dengan pemberian izin nikah beda di Pengadilan Negeri Makassar. Hasil penelitian menunjukkan bahwa fenomena perkawinan beda agama yang terjadi di kalangan masyarakat Indonesia bisa menimbulkan berbagai macam permasalahan dari aspek hukum dan lingkungan masyarakat. Perkawinan beda agama menurut UndangUndang No 1 Tahun 1974 adalah perkawinan yang sah, karena berdasarkan Pasal 2 ayat (1) Undang-Undang Perkawinan No 1 Tahun 1974, perkawinan yang sah adalah perkawinan yang dilakukan menurut hukum masing-masing agama dan kepercayaan. Dari Pasal 2 ayat (1), berbunyi bahwa undang-undang perkawinan menyerahkan sahnya suatu perkawinan dari sudut agama, jika suatu agama memperbolehkan perkawinan beda agama maka perkawinan agama boleh dilakukan, tetapi jika suatu agama melarang perkawinan beda agama, maka tidak boleh melakukan perkawinan beda agama. Berdasarkan hasil penelitian lapangan menunjukkan bahwa setiap agama di Indonesia melarang untuk melakukan perka-winan beda agama. Oleh karena itu, perkawinan beda agama adalah perkawinan yang tidak sah menurut undang -undang perkawinan, serta Hakim juga harus melihat bagaimana rumah tangga pelaku perkawinan beda agama ke depannya, karena sulit terjadi keharmonisan dalam keluarga jika masing-masing pasangan tunduk pada agama yang berbeda, dan rentan perselisihan antar pasangan dalam hal mengasuh anak.
\end{abstract}

Kata Kunci: Perkawinan beda agama, Undang-Undang No.1 Tahun 1974, Penetapan Hakim

\section{ABSTRACT}

This study aims to identify the licensing of interfaith marriages. The study uses qualitative methods, which are sourced from key informant data, documents and interviews as well as material from applicable libraries and are related to granting different marriage licenses in the Makassar District Court. The results showed that the phenomenon of interfaith marriages that occurred among Indonesian people could cause various kinds of problems from the legal aspects and the community environment. Interfaith marriage according to Law No. 1 of 1974 is a legal marriage, because based on Article 2 paragraph (1) of Marriage Law No. 1 of 1974, a legal marriage is a marriage conducted according to the law of each religion and belief. From Article 2 paragraph (1), it states that the marriage law gives up the validity of a marriage from the point of religion, if a religion allows interfaith marriages then religious marriages are permissible, but if a religion prohibits interfaith marriages, then no marriages may be of different marriages. religion. Based on the results of field research shows that every religion in Indonesia forbids interfaith marriages. Therefore, interfaith marriages are illegitimate marriages according to marriage law, and the Judge must also look at how households of interfaith marriages in the future, because harmony in the family is difficult if each partner is subject to different religions, and prone to disputes between partners in parenting.

Keywords: Interfaith Marriage, Law no.1 of 1974, Court Order 


\section{PENDAHULUAN}

Masyarakat Indonesia terdiri atas berbagai suku, budaya, bahasa dan agama, sehingga kecenderungan adanya perbedaan pola pikir yang berbeda sangat besar, dapat kita saksikan dari beberapa kejadian nasional yang melibatkan pertikaian yang mengatasnamakan ras, suku dan agama. Salah satu persoalan yang masih menjadi polemik yaitu persoalan Perkawinan beda agama, permasalahan ini bukan menjadi hal baru dalam salah satu masalah perbedaan pendapat yang ada di Indonesia mulai dari kalangan selebriti sampai ke masyarakat biasa telah melakukan perkawinan beda agama yang masih menjadi perdebatan sampai saat ini mengenai legalitasnya (Joko dan Murtika, 1987; Djubaidah,2010). Menurut Undang-undang Perkawinan yaitu UU No. 1 Tahun 1974 dalam Pasal 1 menyatakan bahwa "Perkawinan sebagai ikatan lahir dan batin antara seorang wanita dengan seorang pria sebagai suami isteri dengan tujuan membentuk keluarga yang bahagia dan kekal berdasarkan Ketuhanan Yang Maha Esa”.

Perkawinan antar agama yang terjadi dalam kehidupan masyarakat, seharusnya tidak terjadi jika dalam hal ini negara atau pemerintah secara tegas melarang dan menghilangkan sikap mendua dalam mengatur dan melaksanakan suatu perkawinan bagi rakyatnya (Asmin,1986; Abdul,2006). Sikap ambivalensi pemerintah dalam perkawinan beda agama ini terlihat dalam praktek bila tidak dapat diterima oleh Kantor Urusan Agama, dapat dilakukan di Kantor Catatan Sipil dan menganggap sah perkawinan berbeda agama yang dilakukan. Dari kenyataan yang terjadi di dalam masyarakat terhadap perkawinan beda agama, menurut aturan perundang-undangan itu sebenarnya tidak dikehendaki. Hal ini sering menimbulkan penafsiran yang berbeda-beda (multitafsir) di beberapa kalangan masyarakat (Bachtiar, 2004). Sebagian ada yang berpendapat tidak sah karena tidak memenuhi ketentuan yang berdasarkan agama mau-pun berdasarkan Undang-undang. Sementara di sisi lain ada yang berpendapat sah sepanjang dilakukan berdasarkan agama/ keyakinan salah satu pihak. Untuk golongan yang kedua ini, mereka akan menganggap sah perkawinan dua orang mempelai yang berbeda agama yang dilakukan dengan cara penundukan sementara pada salah satu hukum agama (Hilman, 1990;2007). Pasangan melakukan perkawinan dengan dua cara, pagi menikah sesuai agama laki-laki, siangnya menikah sesuai dengan agama perempuan. Dari cara ini yang akan menyulitkan adalah untuk menentukan perka-winan mana yang sah dan yang akan didaftarkan pada negara. Hal ini sangat berkaitan erat dengan masalah pengakuan Negara atas perkawinannya yang akan berakibat pada hukum yang berlaku setelah perkawinan.

\section{METODE PENELITIAN}

\subsection{Tipe Penelitian}

Penelitian ini merupakan tipe penelitian hukum kualitatif. Penelitian hukum kualitatif berorientasi pada data yang didapat dari penjelasan narasumber, dokumen-dokumen dan wawancara atau bahan hukum yang berlaku dan berkaitan dengan pemberian izin nikah beda di Pengadilan Negeri Makassar. Penelitian hukum kualitatif dilakukan dengan cara wawancara dengan nara sumber.

\subsection{Jenis dan Sumber Data}

Jenis dan sumber data yang digunakan dalam penelitian ini adalah sebagai berikut Data primer yaitu data yang diperoleh secara langsung dari lokasi penelitian, dan data ini diperoleh dengan cara melalui wawancara atau interview. Data Sekunder yaitu data yang berupa dokumen-dokumen, jurnal-jurnal ilmiah, artikel ilmiah, yang diperoleh dari instansi pemerintah atau swasta yang berhubungan dengan pembahasan tesis ini.

\subsection{Teknik Pengumpulan Data}

Pengumpulan data dilakukan dalam penelitian ini melalui 2 (dua) cara, yakni melalui metode pustaka (library research) dan studi lapangan (field research). Studi kepustakaan dilaksanakan untuk mengumpulkan sejumlah data meliputi bahan pustaka yang bersumber dari buku-buku, artikel, media cetak, dan lain-lain yang berhubungan dengan pembahasan penelitian ini sedangkan Studi lapangan (field research) ini diperoleh dari lokasi penelitian yang berupa hasil pengamatan langsung di lapangan pada saat wawancara dengan Hakim, wawancara dilakukan dengan menyiapkan pertanyaan kemudian dikembangkan pada saat interview, objek wawancara menjawab dengan bebas, tujuannya untuk mengumpulkan keterangan dan pendapat - pendapat mereka.

\section{HASIL DAN PEMBAHASAN}

\subsection{Pertimbangan Hakim dalam Mengabulkan Permo- honan Izin Perkawinan Beda Agama}

Undang-undang perkawinan tidak mengatur perkawinan beda agama. Hal ini menimbulkan beberapa pemahaman. Secara tersirat tidak dibolehkan karena undang-undang tersebut menempatkan keabsahan suatu perkawinan kepada agama masing-masing. Perkawinan adalah sah apabila dilakukan menurut masing-masing agamanya dan kepercayaannya itu. Kesimpulan ini diambil karena agama yang terdapat di Indonesia tidak ada yang membenarkan perkawinan beda agama. Perkawinan beda agama adalah perkawinan yang tidak dikehendaki oleh undang-undang perkawinan. Pada sisi lain, tidak terdapat gambaran bahwa pengaturan undang-undang perkawinan tentang perkawinan campuran tidak lengkap dan masih memerlukan undang-undang lain atau peraturan pelaksanaan. Undang-undang perkawinan sebagai pengganti peraturan perundangan lama memuat pengaturan yang lengkap karenanya tidak ada vakum hukum (Konigsmann, 1989;Hilman, 2003).

Melihat realitas hukum, kalangan masyarakat yang melakukan kawin beda agama yang sebagiannya, melahirkan sebuah pertanyaan apakah sebuah realitas kemasyarakatan merupakan wakil dari rasa keadilan yang hidup di masyarakat. Akankah sebuah realitas secara serta merta dapat dikatakan sebagai hukum yang hidup dan karenanya pantas dijadikan sebagai sumber hukum. Menurut Hakim IMAM SUPRIYADI, S.H., M.H dalam memutuskan sebuah perkara, Hakim harus memiliki dasar yang kuat agar keputusannya dapat dipertanggung-jawabkan. Hakim wajib mencantumkan dasar pertimbangan yang cukup dan matang dalam setiap keputusan. Demikian secara singkat makna kewajiban tersebut, yakni putusan harus jelas dan cukup motivasi pertimbangannya. Dalam pengertian luas, bukan hanya sekedar meliputi motivasi pertimbangan tentang alasan-alasan dan dasar-dasar hukum serta pasal-pasal peraturan yang bersangkutan, tetapi juga meliputi sistematika, argu-mentasi dan kesimpulan yang terang dan mudah dimengerti orang yang membacanya. Beberapa aspek pertimbangan Hakim dalam memberikan izin perkawinan beda agama yaitu Aspek: 


\section{Yuridis}

Dasar yang digunakan Hakim dalam mengabulkan permohonan izin pelaksanaan perkawinan beda agama antara lain:

Negara tidak dapat melarang dan menghalangi seseorang untuk melaksanakan perkawinan. Bahwa berdasarkan kenyataan tersebut diatas maka hakim berpendapat bahwa walaupun pada dasarnya keinginan para pemohon untuk melangsungkan perkawinan tidaklah merupakan larangan berdasarkan Undang-Undang Nomor 1 Tahun 1974 dan pembentukan suatu rumah tangga melalui per-kawinan adalah merupakan hak asasi para Pemohon sebagai warga negara serta hak asasi para Pemohon untuk mempertahankan keyakinan agamanya masing-masing, dan walaupun ketentuan dalam Pasal 2 ayat (1) Undang-Undang Nomor 1 Tahun 1974 tentang sahnya suatu perkawinan apabila menurut tata cara agama atau kepercayaan yang dianut calon pasangan suami istri bukanlah merupakan atau menjadi penghalang bagi para pemohon yang me-miliki perbedaan keyakinan agama untuk melangsungkan perkawinan, mengingat ketentuan tersebut pada hakikatnya merupakan ketentuan yang bersentuhan dengan prosesi atau tata cara penyelenggaraan perkawinan menurut agama calon suami isteri (Monib, 2008;Martana dkk., 2019).

Bahwa menurut Putusan Mahkamah Agung RI No. $1400 \mathrm{~K} / \mathrm{Pdt} / 1986$ tanggal 20 Januari 1989, disebutkan: Bahwa dari azas perbedaan agama dari calon suami istri tidak merupakan larangan perkawinan bagi mereka dan kenyataan bahwa terjadi banyak perkawinan yang diniatkan oleh mereka yang berlainan agama, maka Mahkamah Agung berpendapat bahwa tidaklah dapat dibenarkan kalau karena kekosongan hukum maka kenyataan dan kebutuhan sosial seperti tersebut diatas dibiarkan tidak terpecahkan secara hukum, karena membiarkan masalah tersebut berlarut-larut pasti akan menimbulkan dampak-dampak negatif di segi kehidupan bermasyarakat maupun agama yang merupakan hukum positif, maka Mahkamah Agung berpendapat haruslah dapat ditemukannya dan ditentukan hukumnya.

Berdasarkan pasal 28B ayat (1) perubahan kedua UUD 1945 ditegaskan kalau setiap orang berhak untuk membentuk keluarga dan melanjutkan keturunan melalui perkawinan yang sah, dimana ketentuan inipun sejalan dengan pasal 29 UUD 1945 tentang di jaminnya oleh Negara kemerdekaan bagi setiap Warga Negara untuk memeluk Agamanya masing-masing. Pasal 29 ayat (2) disebutkan, "Negara menjamin kemerdekaan tiap-tiap penduduk untuk memeluk agamanya masing-masing dan untuk beribadat menurut agamanya dan kepercayaannya itu.'

Menurut Undang-Undang Nomor 39 Tahun 1999 tentang Hak Asasi Manusia. Pasal 4, menyebutkan:

Hak untuk hidup, hak untuk tidak disiksa, hak kebebasan pribadi, pikiran dan hati nurani, hak beragama, hak untuk tidak diperbudak, hak untuk diakui sebagai pribadi dan persamaan di hadapan hukum, dan hak untuk tidak dituntut atas dasar hukum yang berlaku surut adalah hak asasi manusia yang tidak dapat dikurangi dalam keadaan apapun dan oleh siapapun.

Berdasarkan pertimbangan Hakim Dalam Perkara No. 488/Pdt.P/2017/PN.MKS adalah:

Bahwa menurut ketentuan pasal 2 ayat (1) Undang-Undang Perkawinan No 1 Tahun 1974 tentang Perkawinan, disebut- kan: (1) Perkawinan adalah sah apabila dilakukan menurut hu-kum masing- masing agamanya dan kepercayaannya itu; dan (2) Tiap-tiap perkawinan dicatat menurut peraturan perundang-undangan yang berlaku:

b. Undang-undang Nomor 1 Tahun 1974 tentang Perkawinan jo. PP No. 9 Tahun 1975, memang tidak mengatur perkawinan beda agama, yang diatur dan dicatat adalah perkawinan dimana pihak-pihaknya seagama dan dicatat oleh Kantor Pencatat Nikah, Talak dan Rujuk bagi yang beragama Islam, serta Kantor Catatan Sipil bagi yang beragama selain Islam.

c. Menimbang, bahwa inti pokok permohonan para pemohon adalah agar para Pemohon diberikan izin oleh Pengadilan Negeri Makassar untuk melangsungkan perkawinan para Pemohon yang berbeda agama tersebut.

d. Ketentuan Pasal 10 ayat (1) Undang-Undang Nomor 48 Tahun 2009 tentang Kekuasaan Kehakiman Bahwa Pengadilan Negeri berwenang untuk memeriksa, mengadili, dan memutus permohonan terdapat dalam Pasal 10 ayat (1) Undang-Undang Nomor 48 Tahun 2009 tentang Kekuasaan Kehakiman, menyebutkan: Pengadilan dilarang menolak untuk memeriksa, mengadili, dan memutus suatu perkara yang diajukan dengan dalih bahwa hukum tidak ada atau kurang jelas, melainkan wajib memeriksa dan mengadilinya.

e. Di dalam penjelasan Pasal 35 huruf a Undang-Undang Nomor 23 Tahun 2006 tentang Administrasi Kependudukan, dimana dalam penjelasan huruf a ditegaskan "yang dimaksud dengan perkawinan yang ditetapkan oleh Pengadilan adalah perkawinan yang dilakukan antar umat yang berbeda agama." ketentuan tersebut ada dasarnya merupakan ketentuan yang memberikan kemungkinan dicatatkannya perkawinan yang terjadi antara 2 (dua) orang yang berlainan agama setelah adanya Penetapan Pengadilan tentang hal tersebut.

f. Sejalan dengan telah ditetapkannya Undang-Undang Nomor 23 Tahun 2006 tentang Administrasi Kependudukan, maka segala kegiatan penyelenggaraan administrasi kependudukan berpedoman pada kebijakan dimaksud termasuk aspek pencatatan perkawinan oleh Lembaga Pencatatan Sipil. Lembaga Pencatatan Sipil sesuai aturan yang berlaku berfungsi antara lain mencatat segenap peristiwa penting termasuk perkawinan,

g. Perkawinan bagi masyarakat yang berbeda agama dapat dicatatkan setelah mendapat penetapan Pengadilan. Sedangkan teknis dalam proses Pengadilan dapat dikoordinasikan dengan lembaga pengadilan setempat.

h. Berdasarkan Undang-Undang Nomor 39 Tahun 1999 tentang Hak Asasi Manusia: Pasal 4, menyebutkan Hak. untuk hidup, hak untuk tidak disiksa, hak kebebasan pribadi, pikiran dan hati nurani, hak beragama, hak untuk tidak diperbudak, hak untuk diakui sebagai pribadi dan persamaan di hadapan hukum, dan hak untuk tidak dituntut atas dasar hukum yang berlaku surut adalah hak asasi manusia yang tidak dapat dikurangi dalam keadaan apapun dan oleh siapapun.

i. Perkawinan yang terjadi diantara dua orang yang berlainan status agamanya hanya diatur dalam penjelasan pasal 35 huruf a Undang- Undang Nomor 23 Tahun 2006 tentang Administrasi Kependudukan, dimana dalam penjelasan pasal 35 huruf a ditegaskan 
kalau "yang dimaksud dengan perkawinan yang ditetapkan oleh Pengadilan adalah Perkawinan yang dilakukan antar umat yang berbeda agama”. Ketentuan tersebut pada dasarnya merupakan ketentuan yang memberikan kemungkinan dicatatkannya perkawinan yang terjadi diantara dua orang yang berlainan Agama setelah adanya penetapan pengadilan tentang hal tersebut, sedangkan terhadap proses terjadinya suatu perkawinan sebagaimana dimasukkan dalam UndangUndang Nomor 1 tahun 1974 dan Peraturan Pemerintah Nomor 9 tahun 1975 tidaklah diatur lebih lanjut dalam ketentuan tersebut. Sehingga terdapat hal-hal yang bekaitan dan proses terjadinya suatu perkawinan itu sendiri baik tentang sahnya suatu perkawinan, syarat-syarat perkawinan, larangan perkawinan, dan tata cara pelaksanaan perkawinan masih mengacu pada ketentuan-ketentuan yang tertuang dalam UndangUndang Nomor 1 tahun 1974.

\section{ii. Aspek Sosial}

Melihat dari penilaian sosial atas uraian-uraian pertimbangan sebelumnya dan dengan memperhatikan faktafakta hukum tersebut diatas, maka Hakim berpendapat sebagai berikut:

a. Suatu perkawinan yang terjadi diantara calon suami dan calon isteri yang memiliki keyakinan agama berbeda tidak merupakan larangan perkawinan, sehingga untuk mengantisipasi terjadinya perbuatan menyimpang di masyarakat apabila tidak diberikannya izin perka-winan maka dikeluarkannya penetapan yang membe-rikan izin perkawinan beda agama selama keduannya saling menghargai satu sama lain tidak memaksa pasangan untuk mengikuti agama salah satu pasangan.

b. Setiap orang berhak untuk membentuk keluarga dan melanjutkan keturunan melalui perkawinan yang sah, di jaminnya oleh Negara kemerdekaan bagi setiap Warga Negara untuk memeluk Agamanya masing-masing, melihat dari hak setiap masyarakat untuk berkeluarga Hakim mempertimbangkan pemberian izin perkawinan beda agama selama tidak ada salah satu pihak yang dirugikan dan akan menimbulkan ketidak harmonisan di keluarga dan bersedia membimbing anak-anak mereka dengan baik tanpa harus memaksa mereka mengikuti agama salah satu orang tuanya.

c. Apabila berdasarkan keterangan para saksi telah memperoleh fakta-fakta hukum kalau para pemohon sendiri sudah saling mencintai dan bersepakat untuk melanjutkan hubungan mereka ketingkat perkawinan, dimana keinginan mereka tersebut telah mendapat restu dari kedua orang tua mereka masing-masing sehingga Hakim memberikan izin perkawinan beda agama karena dengan dasar saling mencintai dan kedua belah pihak keluarga juga menyetujui menjadi pondasi keluarga yang sejahtera

d. Bahwa oleh karena pada dasarnya keinginan para pemohon untuk melangsungkan perkawinan tidaklah merupakan larangan, dan mengingat pembentukan suatu rumah tangga melalui perkawinan adalah merupakan Hak Asasi Para pemohon sebagai Warga Negara serta Hak Asasi para pemohon untuk tetap mempertahankan Agamanya masing-masing, dimana hak setiap orang untuk membentuk suatu keluarga dan melanjutkan keturunan melalui perkawinan yang sah dan menjamin hak kebebasan untuk memilih calon suami dan calon isteri, termasuk perempuan memiliki hak untuk menikah dengan warga negara asing dan bebas untuk mempertahankan, mengganti, atau memperoleh kembali status kewarganegaraannya.

e. Bahwa tentang tata cara perkawinan menurut Agama dan Kepercayaan yang tidak mungkin dilakukan oleh para pemohon karena adanya perbedaan Agama, maka pemerintah memberikan kemungkinan dapat dilaksanakannya perkawinan tersebut, dimana Peraturan Pemerintah ditegaskan "dengan mengindahkan tata cara perkawinan menurut masing-masing hukum Agamanya dan Kepercayaannya itu, perkawinan dilaksanakan dihadapan Pegawai Pencatat dengan dihadiri 2 (dua) orang saksi", dan selama para pihak telah mengerti resiko serta konsekuensi dan tidak ada paksaan dari pihak manapun, Hakim memandang perkawinan beda agama dapat diberikan izin.

\subsection{Mengetahui kekuatan Hukum Penetapan Permohonan Perkawinan Beda Agama}

Perkawinan adalah institusi yang sangat fundamental dalam masyarakat sehingga mendapat perlindungan hukum, hukum selalu membela, mengutamakan, dan memihak pada sahnya perkawinan. Hukum harus berpihak pada kepentingan masyarakat dalam ujud memberi kemashlatan dengan mencapai kemanfaatan atau setidaknya menghindari hal-hal yang menimbulkan kerusakan. Kalau mungkin menggapai keduanya. Von Jhering dalam penjelajahan filsafatnya sampai pada sebuah kesimpulan bahwa bukan ide-ide rasional melainkan kepentingan masyarakat bersifat menentukan dalam hukum. Roscou Pound berpendapat, hukum itu dipengaruhi masyarakat, sementara masyarakat dipengaruhi oleh hukum, aliran sosiologi jurisprudence memandang antara hukum dan masyarakat terdapat hubungan timbal balik (Riduan, 2006; Mudiarti, 2007)

Secara sosiologis hukum merupakan kesatuan kaidah yang bertujuan untuk memenuhi kebutuhan dasar manusia, yaitu kedamaian dalam masyarakat. Menurut Bapak Imam Supriyadi selaku hakim yang pernah menangani kasus perkawinan beda agama, setiap putusan atau penetapan yang telah ditetapkan dalam persidangan oleh hakim adalah bersifat mengikat bagi para pihak. Penetapan tersebut mempunyai kekuatan hukum yang pasti atau tetap selama para pihak tidak mengajukan upaya hukum yang lain. Penetapan hakim mempunyai tiga kekuatan hukum, antara lain kekuatan mengikat, kekutan pembuktian, dan perlindungan hukum yang penjelasannya adalah sebagai berikut:

a. Kekutan Mengikat (bindende kracht)

Penetapan hakim yang dimaksudkan untuk menyelesaikan sengketa perkara dan menetapkan hak atau hukum atas dasar permohonan pihak untuk diselesaikan perkaranya di pengadilan. Oleh karenanya, pihak-pihak harus taat dan tunduk pada penetapan, harus dihormati dan dijalankan sebagaimana mestinya. Jadi mempunyai kekuatan mengikat (bindende kracht).

b. Kekutan Pembuktian (bewijzende kracht)

Penetapan hakim dituangkan dan dibuat dalam bentuk "akta otentik". Maksudnya untuk bukti (pembuktian), yaitu mempunyai kekuatan bukti terhadap pihak ketiga (pihak luar). Demikian pula karena sebagai kekuatan pembuktian maka penetapan dapat digunakan untuk alat bukti bagi para pihak saat akan mengajukan upaya hukum atau pelaksanaan penetapan tersebut. Perlu diketahui bahwa apapun bunyi sebuah penetapan hakim, maka penetapan hakim tersebut dianggap benar (res judicata pro veritate habetur). 
Kekuatan pembuktian ini maksudnya adalah apabila ada pihak yang ketiga menyangkal tentang sahnya perkawinan beda agama para pihak, para pihak sudah mempunyai bukti tentang sahnya perkawinan tersebut yang dapat dilihat dari Penetapan Perkawinan Beda Agama tersebut. Apabila perkawinan tersebut telah dicatatkan pada Pegawai Dinas Kependudukan dan catatan Sipil Kota Makassar maka para pihak yang melakukan perkawinan secara otomatis mendapatkan Akta Perkawinan, yang dapat menjadi bukti bahwa para pihak telah sah melakukan perkawinan (Soemityati, 2007; Subekti dan Tjitrosudibio, 2013).

c. Perlindungan Hukum

Penetapan yang diberikan Hakim bersifat melindungi setiap warga Negara yang mendapat izin melaksanakan perkawinan beda agama sehingga tidak ada pihak-pihak yang dapat melakukan intimidasi terhadap orang yang melaksanakan perkawinan beda agama, tetapi Hakim juga seharusnya melihat aspek dari pandangan agama yang dianut oleh masyarakat Indonesia sebagai perlindungan hukum bagi masyarakat yang melakukan perkawinan beda agama, karena penetapan pengadilan merupakan putusan tingkat pertama dan terakhir sehingga upaya hukum banding tidak dapat dilakukan terhadap penetapan, namun menurut penulis Hakim juga harus mempertimbangkan tanggapan-tanggapan dari tokoh agama mengenai perkawinan beda agama

\section{KESIMPULAN}

Berdasarkan hasil penelitian, maka dapat disimpulkan bahwa, Pertimbangan Hakim di Pengadilan Negeri Makassar dalam memberikan penetapan izin kawin beda agama selalu melihat dari 2 (dua) aspek yaitu aspek Yuridis dan aspek Sosial sehingga mengeluarkan penetapan pemberian izin kawin beda agama karena para pemohon sendiri sudah saling mencintai dan bersepakat untuk melanjutkan hubungan mereka ketingkat perkawinan, dimana keinginan mereka tersebut telah mendapat restu dari kedua orang tua mereka masing-masing, namun penulis melihat hakim harus mengambil beberapa pertimbangan sebelum memberikan penetapan karena pemohon yang ingin kawin beda agama selalu berlindung pada aturan Hak Asasi Manusia yang memperbolehkan setiap orang untuk menentukan pilihan hidupnya termasuk dalam memilih pasangan tanpa melihat konsep dari ajaran Agama, sehingga penulis berpendapat jika Hakim tidak lagi memberikan izin perkawinan beda agama bagi masyarakat yang mengajukan permohonan dengan alasan para pemohon sudah tidak lagi mengikuti hukum agama mereka padahal Negara kita menjunjung tinggi hukum Agama masing-masing; Kekuatan Hukum Penetapan Kawin Beda Agama terhadap penetapan yang dikabulkan oleh pengadilan Nomor 488/ Pdt.P/2017/PN bersifat mengikat, jadi dasar Pembuktian, dan memberikan perlindungan Hukum bagi pemohon yang akan nikah beda agama untuk mencegah adanya protes dari masyarakat yang tidak senang dengan perka-winan mereka, sehingga saya tidak setuju dengan tindakan yang dilakukan Hakim karena penetapan yang dikeluarkan Hakim merupakan suatu yuris prudensi serta mendapat perlindungan dari negara dan karena perkawinan merupakan suatu ikatan bersifat privat sehingga jarang masyarakat yang menghiraukan persoalan tersebut padahal jika dibiarkan perkawinan beda agama bisa berdampak menurunnya kualitas keluarga Indonesia ke depannya karena menjadikan masyarakat lebih egois tanpa melihat aturan Agama yang merupakan pondasi utama hidup bermasyarakat yang baik.

\section{DAFTAR PUSTAKA}

Abdul Manan. (2006). Penerapan Hukum Acara Perdata di Lingkungan Peradilan Agama, Jakarta, Kencana

Asmin. (1986). Status Perkawinan Antar Agama Ditinjau Dari Undang-Undang Perkawinan No 1/1974. Cet 1. Jakarta: Dian Rakyat.

Bachtiar, A. (2004). Menikahlah, Maka Engkau Akan Bahagia!. Yogyakarta : Saujana

Djoko Prakoso, \& I Ketut Murtika, 1987, Azas-Azas Hukum Perkawinan di Indonesia, Bina Aksara

Djubaidah. (2010). Pencatatan perkawinan dan perkawinan tidak dicatat, Keterpurukan Hukum Di Indonesia, Jakarta: Sinar Grafika.

Hilman Hadikusuma. (1990) Hukum Perkawinan Indonesia Menurut Perundangan, Hukum Adat, Hukum Agama (2007). Hukum Perkawinan Islam dan Undang-Undang Perkawinan, Liberty

Hilman Hadikusuma. (2003). Hukum Perkawinan Indonesia, CV. Mandar Maju, Bandung.

Johni, Konigsmann, 1989, Gerakan dan Praktek Ekumene, Nusa Indah

Martana, N., Martana, P. A. H., Sudiarawan, K. A., \& Hermanto, B. (2019). Discourses of Legal Certainty in Execution of Administrative Court Decision. Substantive Justice International Journal of Law, 2(2), 89-117.

Monib, Nurcholish. (2008). Kado Cinta Bagi Pasangan Beda Agama, Gramedia Pustaka Utama

Mudiarti Trisnaningsih. (2007). Relevansi Kepastian Hukum Pengaturan Perkawinan Beda Agama di Indonesia

Riduan Syahrani. (2006). Seluk beluk Asas-asas hukum perdata, (Banjarmasin; PT. Alumni).

Soemiyati. (2007) Hukum Perkawinan Islam dan UndangUndang Perkawinan, Liberty

Subekti dan Tjitrosudibio. (2013). Kitab Undang-Undang Hukum Perdata (Burgerlijk Wetboek) dan UU No. 1 Tahun 1974. Jakarta: Pradnya Paramita 